\title{
The Politics of Song
}

Music for Kings, Music for Empire, c. 1400-1722

In the city of Isfahan, several palaces still stand from the Safavid Dynasty, which ruled over the Iranian Plateau around 1501 to 1722 . The Safavids invested much in the grand appearance of their persona, overseeing the building of great architecture and a renaissance in visual art that surpassed their Timurid, Mongolian, and Turkmen predecessors. In their 'Ali Qapu Palace one can still visit the Safavids' so-called music room: a very ornate room for courtly entertainments with a very effective acoustical design (see figure 5). Inside the Safavid Palace of Forty Columns (chehel sotūn), musicians appear in multiple murals. Depictions of different Safavid rulers engaging in the dynastic duties of fighting and feasting (razmo bazm) appear in the reception hall of this palace, where contingents of musicians and dancers appear in the murals of feasts. One commemorates the reception of the Mughal ruler Humayun in the Safavid court by Shah Tahmasp I (r. 1524-1576) (see figure 6). Another depicts Shah 'Abbas I (r. 1588-1629) hosting the ruler Vali Muhammad Khan from Bukhara (see figure 7). The Shah who built the palace, Shah 'Abbas II (r. 1642-1666), appears in a third mural welcoming another ruler from Central Asia, Nader Muhammad Khan.

Both the music room and the murals are part of a larger representation of Safavid power that was meant to be seen. Shah 'Abbas I initiated the building of 'Ali Qapu palace as a grand entrance to the Safavid domain, right on the main square of the Safavid capital. In the reception room at the Palace of Forty Columns, the murals of Tahmasp I, 'Abbas I, and 'Abbas II are on display in a room dedicated to receiving visitors. The murals of feasts all feature large amounts of wine, food, and musical entertainment laid out in front of the royal entourage, which is organized in a V-shaped formation pointing toward and the prominently positioned shah. 


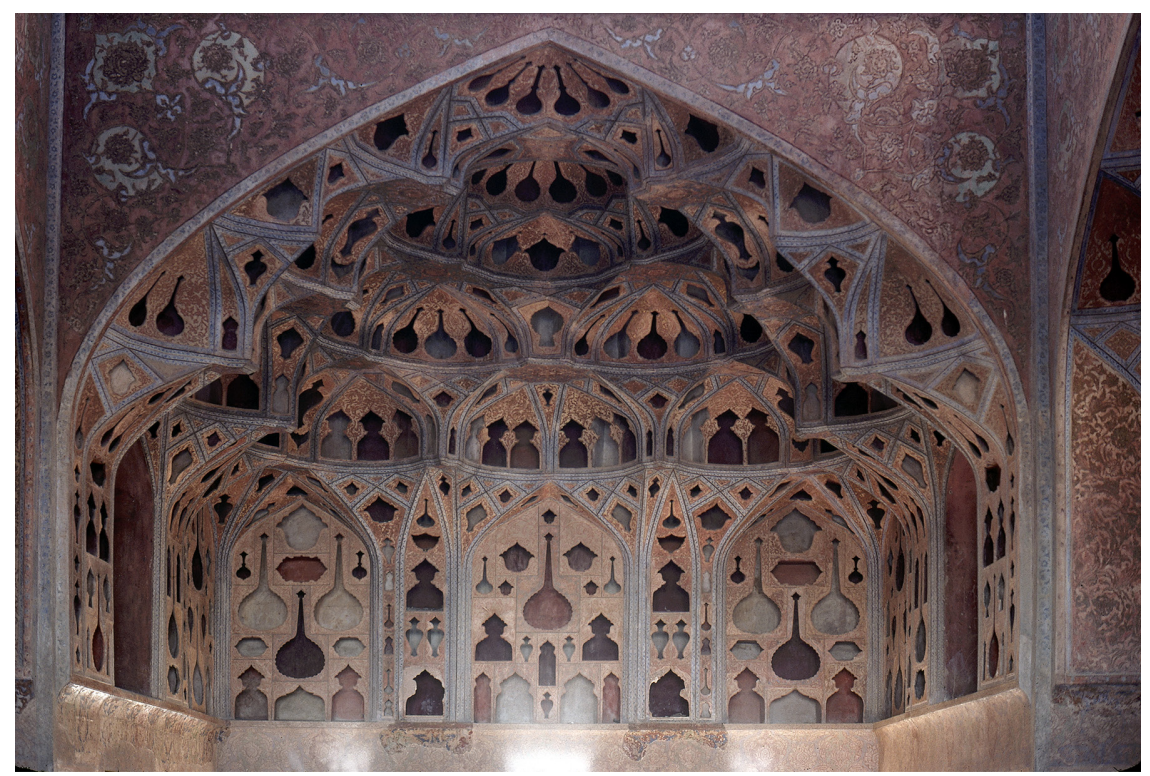

Figure 5. High Wall in the "Music Room" of the "Ali Qapu Palace. Photo by Sheila Blair and Jonathan Bloom.

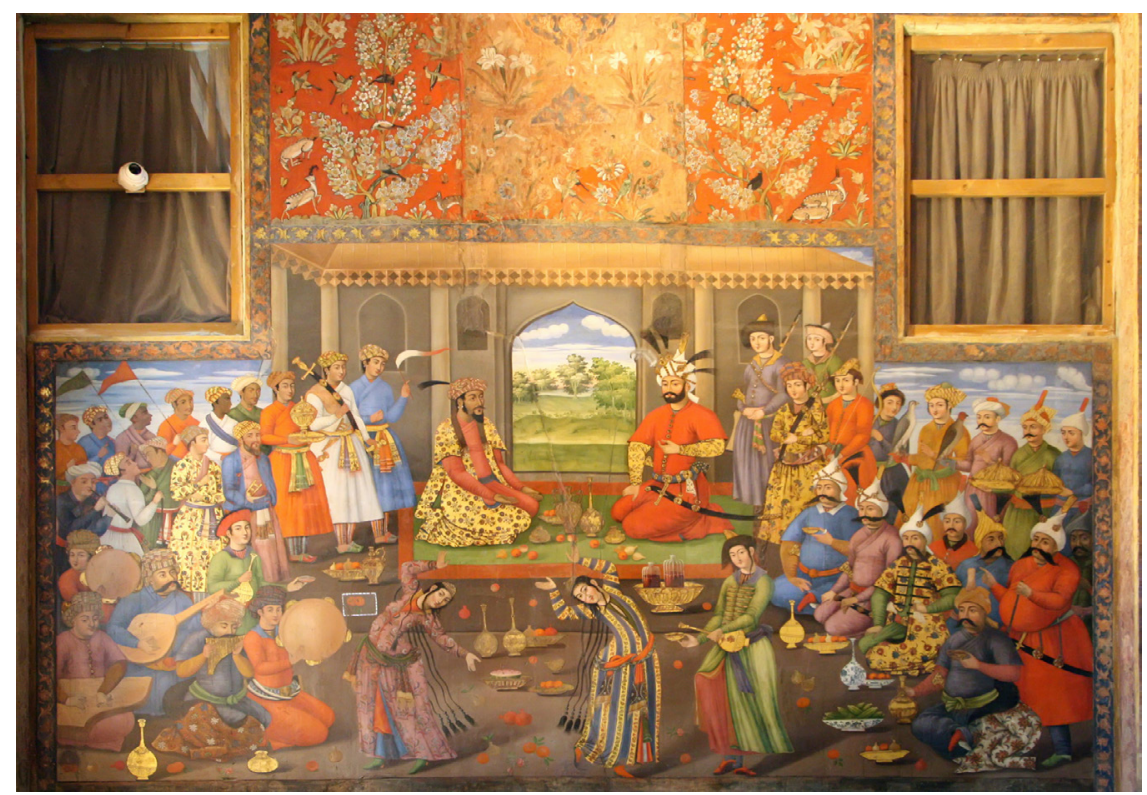

FIGURE 6. Mural of Shah Tahmasp I with Humayun in the Palace of 40 Columns. Photo by Muhammad Mahdi Karim. Licensed GFDL. 


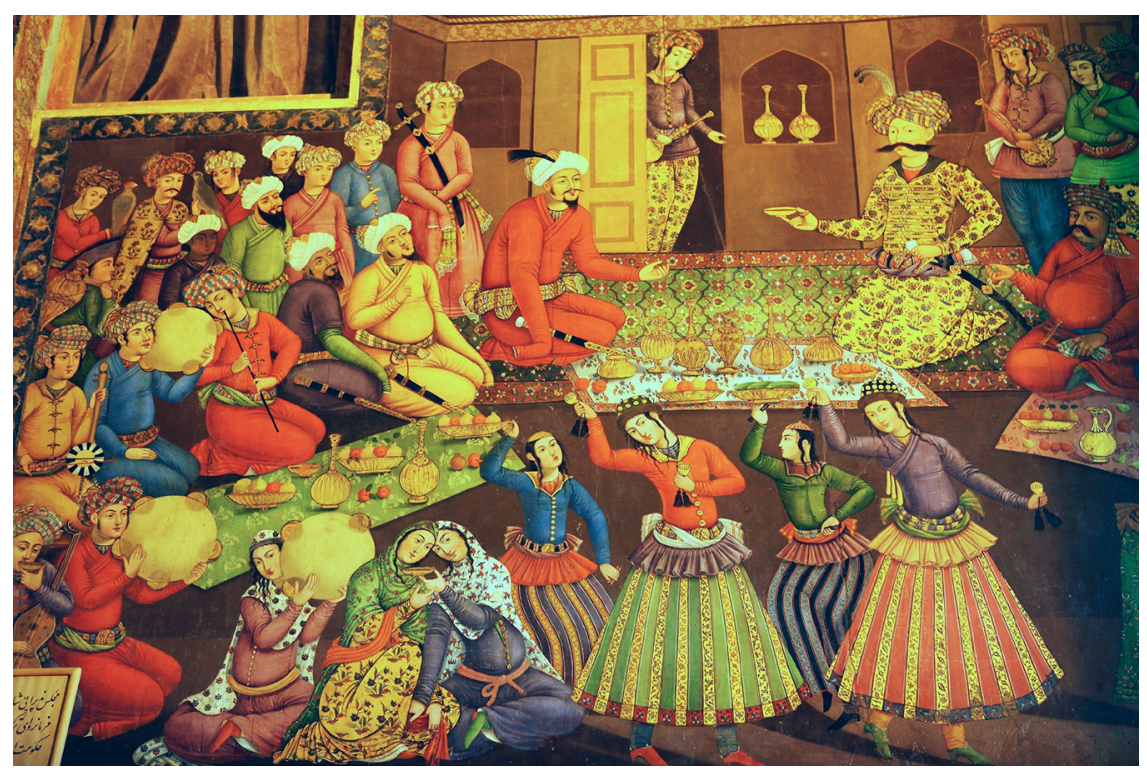

FIgURE 7. Close up of the mural of Shah 'Abbas I with Vali Muhammad Khan in the Palace of 40 Columns. Photo by Kaisu Raasakka.

The visiting rulers are depicted as humbling themselves in front of their Safavid hosts. Such scenes visualize music as part of the depiction of dynastic authority: the vision of the dynast as the sole claimant and controller of an immense bounty of resources, which he benevolently made accessible to those who would subject themselves to his authority.

Speaking with Iranian musicians today, I was surprised to hear that they largely view the Safavid Dynasty as a low point in the history of Iranian music. In current narratives, Persian music was budding anew at the end of the Caliphate in the thirteenth century. The Ilkhanate and its offshoots had a role to play in this, but the musical renaissance reached its zenith under the Timurids in the fifteenth century, with some input from the courts of their Turkmen competitors. This renaissance somehow collapsed at the beginning of the sixteenth century, when the Timurids fully succumbed to the Safavi, whose reign ushered in a period of musical decline. This narrative among Iranian musicians goes back at least as far as the mid-twentieth century, but I found its ongoing resonance curious. Iranian musicologists have done much research on music of the Safavid Empire since 1978, and found much music-making under court patronage during their reign. Timurid art did not feature large murals of Timurid feasting with musical entertainment, nor is there any known Timurid architecture that featured an acoustically distinct room particularly well suited for musical entertainments. Other Mongol and Turkic rulers also did not demonstrate interest in such conspicuous demonstrations of their courts' 
musical consumption. These Safavid predecessors did have miniature paintings within illuminated manuscripts, which depicted various scenes described in the text, among them the same kinds of feasting scenarios valued by the Safavids, albeit on a much smaller scale. The Safavids also had their own elegant illuminations, with beautifully appointed feasting scenes including musicians that, once again, outshine their predecessors. Looking at the visual art, music appears quite valued in the Safavid Realm.

The most common reason musicians cite for Safavid musical decline is the rise of Shi'a Islam. The Safavids' historically unique association with Shi'ism was an important defining feature of their rule, and many Safavid rulers demonstrated a zealous commitment to their particular religious predilections. Indeed, a few Safavid rulers banned music in their courts at various points during their reign. For instance, music was a very active part of Shah Tahmasp I's court, until he decided to dedicate himself more fully to a religious lifestyle. In making this change he did away with his court musicians and those of his princes, though he kept his military band and it seems musicians found their way back into the Safavid court shortly after his death.

In a somewhat more consistent contradiction, there was an active outcry against music (ghina $\bar{a}^{\mathrm{e}}$ ) from multiple Shi a clerics of the Safavid Empire. Indeed, these writings demonstrate a high degree of moral disapproval for music, though the issue was not a settled one in clerical circles. One issue appears to have been the relatively new position of Shi ism as the primary conduit between dynastic and religious authority. Shi'a clerics had to be initially imported to create the structural link between dynast and religion, and Sufism was not so easily replaced in the power structures of empire. Before their rise to power, even the Safavids had been involved in a very heterodox version of Islam that presented a combination of Shi ism and the types of mystical ideas and practices more closely identified with Sufism. While the development of their own Shi a orthodoxy from the beginning of Safavid rule under the Isma il I (1487-1524) specifically put Sufi sects out of the court, Sufism occasionally crept back in, even in the midst of Shi a authority. In this context, Shi a outcry against music using moral rhetoric could not be entirely separated from the new clerical class's need to represent and distinguish their own political power vis-à-vis competition from Sufism. Shi a attacks on music as immoral related closely to Shi a critiques of Sufism, and these critiques had very strong political motivations. ${ }^{1}$

These particular instances of religious equivocating on the question of music's moral acceptability provide the frameworks for Shi' ism to stand as a primary factor in notions of Safavid musical decline. But there were other signs that music's situation had changed within their empire. Sufi writings became scarce in the Safavid Empire, including writings about sama', as Sufism's influence waned in political circles. More significantly, Persian writings about the twelve-maqam system from the Safavid Empire are somewhat different than those written in the 
five centuries previous. Safavid musical writings repeat themes of earlier writings, but do not often elaborate on technical issues. The mathematical quantification of intervals, the systematic construction of scales, and various complicated topics regarding the interworkings of sound and musical instruments largely disappear in the Safavid Realm. There is an intellectual sophistication in writings about music before their rise to power that disappears under their rule.

With complex, technical explanations of music out of the picture, metaphysical tropes became a more central focus of Safavid discussions of the twelve-maqam system. This new focus in writing spent more time drawing basic parallels between the twelve-maqam system and the prophets, the planets, the zodiac, various times of day, seasons of the year, and so on. While the basic idea of these types of associations had precedence in earlier Persian music treatises, they appear as a welldeveloped focal point that comes to define Safavid writings about music. There were even new congruencies, as the forty-eight gusheh had to be accounted for and new aspects of nature were added, such as associations between the twelve maqam and the vocalizations of different animals.

These very symbolic representations of the system appeared with some general reporting on musical forms and song structures that were unique to the Safavid era. But while much writing about the twelve-maqam system from before the Safavid era required a lengthy and dense style of writing, such cerebral writing was less relevant in the Safavid Empire. Conversely, poetic descriptions of the twelvemaqam system increased in Safavid writings about music, which ultimately valued clear structural style over and above a greater degree of detailed musical substance.

Complex questions concerning topics such as the nature of consonance versus dissonance and proper intervallic relationships of pitch had been the legacy of earlier musical thought in Graeco-Arabic writings preceding the twelve-maqam system. Writings about music in the Safavid Realm express no specific knowledge of this philosophical tradition, which had directly informed much writing about the twelve-maqam system in the Persian language before the sixteenth century. It is this lack of conscious education in specific musical concerns of the adjacent past that makes Safavid writings on music appear to be "in decline": they forget so much of the intellectual context for music's conception in previous centuries.

Additionally, representation of the twelve-maqam system waned in Safavid territory as the empire itself declined going into the eighteenth century. Even as this happened, the twelve-maqam system maintained relevance in the Moghul Empire, where it was often put side by side with descriptions of South Asia's rag/ragini system. Thus the twelve-maqam system went from the mostly commonly held understanding of a universal music system, to being just one possible interpretation of such a system in the wake of the Safavids' demise.

Some contingency affected music discourse in the Safavid Realm and its ability to mirror fully past musical priorities. It appears that knowledge of the twelvemaqam system dispersed from the Timurid Empire into the Safavid, Ottoman, 
and Mughal Empires following the Timurids' final fall. One famous example of this dispersal is the family of the self-made musical sage Maraghi, who found themselves practicing music in the Ottoman courts, bringing some of their ancestor's knowledge with them. While this well-documented aspect of Turkish music history is the proverbial elephant in the room of Iranian music history, it was largely business as usual in the history of cosmopolitan Islamic Empire. The musical legacy of the Timurid Empire did not simply descend directly to the Safavids: musicians would ultimately end up in a variety of different courts across several different dynastic realms.

Other key contingencies affecting music in the Safavid Empire related to issues of size and longevity. For all of their visual grandeur, the Safavids had a relatively small and short-lived kingdom compared to their imperial Muslim neighbors. This did not make the Safavids bastions of musical austerity, but it did limit their ability to patronize music to the same extent as their dynastic contemporaries and predecessors, regardless of any Safavid rulers' religious or political predilections. It also meant that musicians who worked in the Safavid courts ultimately would have to move into the courts of the other surrounding empires if they were to survive after the fall of the Safavids in 1722. In the wake of the Afghan invasion, the end of Safavid rule created an unusually large power vacuum, which for several decades left musicians without a new, stable basis for aristocratic patronage in former Safavid lands.

The sixteenth century was a moment of broad political change across Western, Central, and South Asia. The Safavids, Ottomans, and Mughals all ran more centralized empires than had been previously possible even a century before. The changes that allowed for their various approaches to centralization were in part a result of new technologies-including military technology-earning them the title of "gunpowder empires." Thus the ongoing pursuit of the empire for more land and more resources continued, with new mechanisms that gave rulers a greater ability to more directly administer lands and resources under their control. While they all hand some of the same technological tools, each of the three empires centralized their authority in different ways. The Safavids specifically had unique ways of centralizing their control over music. Beyond visual representations of music, musical performance had some new and unique roles to fulfill under Safavid administration. These included Safavid administered Shi'a ceremonies with music, where Safavid shahs could act out their associations with divinity. Recitations of epic poetry in coffeehouses also came under Safavid control for a time, becoming one of several professionalized jobs with a guild organized and administered by the Safavids. ${ }^{2}$ In this context, the Safavids relationship with music was not unique in its moral rejection of music, or failure to patronize it. It was unique because the Safavids often had a more direct political investment in musical activities than their predecessors as well as a greater ability to directly manage music to suit their purposes. 
Even in the midst of this different kind of empire, the basic themes and premise of Safavid writings about music in comparison with writings of the previous Timurid and Ilkhanate realms were not so different. The twelve-maqam system was still the central concept of musical structure, with the additional extension of the gusheh derived from the system's foundational derivative concept. Safavid writings took their primary themes and focus within discussions of the twelvemaqam system from previous trends, with different emphasis on what mattered most in music's structure and expression. Even the positioning of an alternative music system next to the twelve-maqam system had precedence in earlier writings. The differences between the twelve-maqam system under the Safavids and their predecessors was thus significant, but not a wholly separate phenomenon.

In considering how the political changes from the Timurid Period to the Safavid Period affected the twelve-maqam system, topical expression in song is a useful source for analysis. Song texts-the words to songs associated with performance in the twelve-maqam system-tell a story about the life of the court and the aristocracy extending out from dynastic centers of power. Song texts represent a key nexus between music and its cultural contexts within dynastic aristocracies of Islamic Empire. While song text collections are the least common type of premodern musical writing in Persian, they appear next to discussions of the twelvemaqam system and provide strong insight into the pursuits of music's courtly audience. They give a musical voice to the image and interests of the court, laying out what courtiers considered important at any given time. Song texts demonstrate differences between Timurid and Safavid politics consistent with differences in how each dynasty ruled, and the different role of music in relation to each dynasty's distinct dynastic façade. Music in a dynastic context had certain implications for how the twelve-maqam system would be discussed and applied. Conversely, songs from the Timurid and Safavid courts express the different roles music could have within different dynastic contexts, while demonstrating how these differences affected discourse about the twelve-maqam system.

The earliest Persian song text collections that speak to the complications of music in their dynastic political context are from 'abd al-Qader al-Maraghi, who recorded song texts as forty-five courtly gatherings (referred to as majles) in his treatise the Jāmi al-alhān in Herat between 1405 and 1413. Maraghi indicated that courtly gatherings commonly focused on a single theme and thus recorded song texts according to theme in this collection without defining or referencing any performance information about different songs. In this collection, the focus is on the court itself: how it organized its entertainment and approached its reflection on topics of import to the court. A second, smaller anonymous collection attributed to Maraghi contains songs recorded separately, according to their maqam, usul, and musical form. Though there is no name associated with this collection, one song references the year $813 \mathrm{AH} / 1410-1411 \mathrm{AD}$. The date in this song places the collection within Maraghi's years of courtly service and together these two col- 
lections represent the interests of the dynastic aristocracies Maraghi ultimately served in both the Jalayarid and Timurids Dynasties.

Under the Safavids, two different song text collections have survived in a compilation of writings about music that Shah Husayn (r. 1668-1722) ordered to be created by his head of court musicians, Amir Khan Gorji. Amir Khan labeled his official accounting of Safavid musical writings with the year 1697, more than two decades before the Afghan Invasion. In this formal legacy document, Amir Khan included two collections: one that he put together himself and another from Aqa Momen Mosannef. Aqa Momen was the head of court musicians during the first half of the seventeenth century. His collection only included songs he personally wrote for multiple Safavid rulers. Amir Khan was the head of court musicians at the end of the seventeenth century, and as the person charged with creating the compilation he included both his own compositions and those of other musicians. $^{3}$ Most of Mosannef's songs mention the maqam they were sung in, while Amir Khan's songs provide much more information about how the song was performed, including the maqam, the usul, and the musical form.

While music treatises are part of the larger corpus of writings associated with the wisdom produced and maintained by various Persianate Islamic courts, collections of courtly song texts function as more explicit documents of dynastic legacy. While the smaller anonymous collection appears to be a functional reference for the head of court musicians, the rest of these collections are organized to put forth an image of court life for the benefit of the court and the image of the dynasts. They do not contain every song enjoyed at the court, yet they do contain a series of representative poetic content and themes, and key among these themes is the shah, also referred to as the sultan or the king (khusraw). The shah is the ruler of civilization: the one who controls people, land, and resources via military strength, dynastic power, and divine affirmation. It is the representation of the shah in song in the context of other courtly interests that reveals how the realities of the dynastic realm impacted music-making within the twelve-maqam system, and what changed in music from the Timurids to the Safavids.

\section{SINGING FOR THE JALAYARIDS AND TIMURIDS}

Songs with religious themes have a special place in Maraghi's collection of forty-five gatherings. Thus, the first gathering he records begins with the following song:

Praise to God, who created life from nothingness;

From this nothingness shedding light on eternal secrets

He remains in his kingdom, so glorious yet so humble

$\mathrm{He}$ is shelter for every wanderer, help for those who are helpless

$\mathrm{He}$ is the consoler of those who are sorrowful, the forgiver of those who are penitent. ${ }^{4}$ 
Though not the most common themes of the collection, the topics of God, the Prophet, and early Islamic leaders are featured prominently among Maraghi's forty-five gatherings, positioned at the beginning and the end of the collection, where they frame his full anthology. As the opening song text of the first gathering, this song contributes to the only gathering dedicated to honoring God directly. In the midst of devotion to God, the song uses imagery of the shah in order to depict the greatness of God. Thus one section sings:

Oh great shah, still and as yet

Sustainer without limit, creator without death

Your sea of mercy, exonerated of scorn

You are the everlasting king, exonerated of death.

The power of the shah described in this phrase is used to anthropomorphize the power of God. This metaphoric use of the shah extends into gatherings dedicated to the initial founders of the Muslim community, even as the songs begin to reference actual leaders. While the Prophet of Islam is always the Prophet, he is praised alongside his companions, which brings praise for kingly attributes of the early Caliphate. Thus, the third gathering is dedicated to singing the praises of 'Ali, the Prophet's cousin and an early caliphal leader. Here the song utilizes the imagery of battle and military prowess to expound his spiritual qualities. It sings, "His sword is the celebrated illuminating torch of religion; 'Ali is the lively horseman of the battlefield of chivalry."'

This imagery becomes more literal in the final gathering of the collection, which is also dedicated to songs about the companions. In this gathering a song refers to "Ali as "the shah of the people of God" while referring to another companion and caliphal leader, 'Uthman, as "the sultan of the world." The metaphor of the shah is replaced here by veneration of actual rulers of the Islamic community, whose leadership roles relate to the concept of dynastic rule.

In Persian poetry of Maraghi's time, imagery of the shah is used in the praise and description of God, while the emphasis on the kingly qualities of Islam's earliest leaders provides a basis of association between the early leaders of the Muslim community and contemporary rulers. This portends the centrality of the shah in all kinds of song texts recorded by Maraghi. The legitimacy of the shah could be established through religious affiliation, even as the power of the shah imbued religion with authority. While Islamic figures are singled out for unabashed praise in key places in his collection, the generalized trope of the shah is used to ponder many ideas, moods, and occasions throughout songs recorded by Maraghi. Using the title of shah as a symbol of powerful glory is only one side of this trope, with other perspectives being reflective, pessimistic, and even negative as the figure of the shah is used to extrapolate larger issues of the human experience. While God was a shah with everlasting life, songs in Maraghi's fourth gathering are dedicated 
to recognizing the morality of the shah on Earth. In one song, the shah speaks to himself about the limits of his own human power:

I could finally conquer the world like it is my body, within the control of my mind

I conquered thousands of castles with a movement of my arm

I broke thousands of hearts with the tread of one step

Thousands of kings are falling humbly prostrate in front of me

I have thousands of slaves standing prepared ready to obey my orders

At the arrival of death, none of the flags and drums could save me

Neither my Arab nor Turk army nor the army of mourning and crying

Death comes and I do not benefit from my military strength

The army of war cannot help me, nor the officers, nor the ability to retreat. ${ }^{7}$

In this moment of reflection, the resources and military power of the shah are showcased, even as death is positioned as the only thing that could defeat the ruler, just as it defeats all mortal things. In the first gathering, the power of the shah was emblematic of the power of God. In this gathering, he is the conqueror of this world, but not of the next. This use of the shah to emphasize the inescapability of death has a historical dimension. Another song from the fourth gathering sings, "Read the story of the shahs of the world, of Hoshang, Jamshid, and Chingiz-Khan. ... Many obtained the gold, the crown, the throne, and the treasure through great difficulty. But except for a good name they took none of this with them." ${ }^{8}$ The legendary greatness of shahs of the past and their inability to escape death highlight both the inevitability of the shah's death and the ongoing importance of a shah's legacy long after his death.

While the fourth gathering points to the general importance of a shah's legacy after death, the eleventh gathering focuses on addressing the legacy of rulers who mistreated their subjects in the distant past. Here songs single out Persian rulers before the age of Islam as examples of repressive rulers and their ultimate destiny:

Have you heard about the Persian ('ajam) Kings?

They committed injustice against their subjects

Their power and sovereignty did not last

The oppression of the people did not last

Within the endurance of cruelty, injustice might end

Injustice endured and it departed with grievances

The dry lips of the oppressed smile

As they tolerate the cruelty ...

Life passes like the prairie wind

My good, bad, beautiful, and ugly days passed me by

The tyrant thought he was oppressing us for life

Eventually, [though], it ended for us but it will remain on his shoulders for good. ${ }^{9}$

Like the song that referenced Hoshang and Jamshid, this song focuses on the stories of ancient kings from before the time of Islam, even invoking a style of Persian poetry found in Ferdowsi's Book of Kings, dedicated to these legendary 
figures. While stories associated with Ferdowsi's text are generally affirming of the shah and dynastic governance in general, this gathering references a grimmer view of the who these rulers were and what lessons could be learned from their legacies. While the shah is always a figure of great power endowed by both religious and military strength, this power could be used in various ways, good and bad. The power of shah came with perils, including how the bad actions of the shah would be remembered forever, unlike those of his subjects.

In the midst of songs that provide complex perspectives on the shah are gatherings dedicated to the more basic task of celebrating the contemporary rulers according to the specific occasions for a courtly gathering. Thus, in the gathering recorded for the celebration of the springtime new year's holiday (nawrūz), praise for the shah is in order:

Oh, Shah! Have a good time and be happy with your holiday

In the everlasting joy, may your holiday be happy

Oh, imperial monarch! The unparalleled God

Gave you dignity and livelihood, may your holiday be happy

Indeed, today, you are the refuge for the faith

The universe is the body and you are the soul, may your holiday be happy

People are joyful and feasting as long as you are on the throne

Have another round of wine; may your holiday be happy. ${ }^{10}$

Likewise, in the gathering happening upon the birth of a shah, the songs are equally lauding:

It is the birthday of the king of all kings of the world today

The effect of God's kindness is appearing again today

On the throne for all eternity

God giving good tidings of his prosperous fortune

It is the day of the emergence of the symbol of the secret of the two worlds

It is the birthday of the genuine son of Adam

Bravo, Oh goodwill of everlasting delight

Hail, oh dweller of the house of happiness and peace. ${ }^{11}$

Beyond these very formal occasions, the anonymous song text collection contains a song in which the singer pines for the shah in his absence:

When you go to Iraq, Shah, do not forget me

You remain with me in that separation, Shah, do not forget me

You are celebrated; this journey yields your prerogative, victory, and triumph

Return with the gratification of the heart, Shah, do not forget me

All of your work is victory; it is victory and triumph every day

Your day is all light and plenty, Shah, do not forget me. ${ }^{12}$

In all of these ways, the shah is a very prominent, common, trope in the songs of the Timurids and their contemporaries. While there is an ample amount of praise and devotion, there are also texts that reflect on the limits, problems, and 
risks of kingly power. Throughout all of these songs the shah is treated primarily as a concept rather than a specific person. Specific examples of rulers are pulled from history to explain more general themes and lessons for contemporary rulers for whom the songs were written. However contemporary rulers themselves are conspicuously absent. Not even songs voiced directly to contemporary rulers mention anyone by name. The trope of shah in these songs embodies an abstract figure that may be good or bad. He might be a cherished companion or an unapproachable figure of mythic proportions, yet always the shah is central to human existence and powerful up until the moment of death. The kingliness of religious figures represents part of their greatness, even as the shah personifies the greatness of God, and legendary shahs teach lessons about the nature of the institution.

While the shah is the most oft repeated subject of the song texts recorded by Maraghi, many songs address a variety of topics, independent from kingly matters. For instance, in Maraghi's nineteenth gathering songs discuss hospitality for strangers in need of assistance:

To the house that the guest enters

The homa bird (homa) of the lote tree lands on its threshold

What a great thing the prosperity of the lucky star, that one night like the moon

Comes down to my cottage without caravansary and without lord....

While I am the guest at the table of kindness

The strength of injustice is weakened

Be good and generous to the guest

Because it is advised by the Prophet to "serve your guest." 13

In the anonymous collection, one song ponders the short duration of youth and the prospect of growing old:

I have become old and replete with years of existence, yet I remain amazed

That life's sweetness has passed

I am in reflection and amazement of it

Because I do not know any amount of youth; I did not know, I would not know

That life is a valuable source I lost so cheaply

What benefit would wailing and crying bring?

The arrow from the bow is worn

But what is obtained from regretting?

When the bird has flown the cage

Look at the hand, empty and black, yet I am not regretful

I hope for nothing except mercy and repose. ${ }^{14}$

The nineteenth gathering has peripheral references to the shah and religion, mentioning the advice of the Prophet and referring to the luck of the mythical homa bird, which can confer the title of shah upon anyone it chooses. This 
anonymous song reflects on the realities of age and frailty associated with basic humanity. The shah is powerful in life and gone in death, but humanity in general grows weak with old age.

The themes of mysticism and romantic love, while central to the Persian poetry of Maraghi's era, are not more dominant in his collections than the shah. They do, however, make appearances in his collections. Maraghi records only one gathering dedicated to Islamic mysticism, containing a song about sama:

Knowledge of sama' makes one dance

Until the fire of its zeal forces one to sit for a moment

The wise know that the wet nurse at the child's crib

Rocks the cradle the calm the child....

Play in a light-hearted way, oh musician, out of kindness I play

Offer the heavy goblet of the cupbearer; from his hand I am so happy

Who is the musician that tonight comes to this place (maqām)?

Play the melody (pardeh) of 'oshshāq and do not hide behind the curtain (pardeh)

Make the gathering warm with one such melody

So that the wine starts to boil; sweat trickles from the embers

If my heart moves on, talking about different things

It comes around to the right way because it hears his voice

The rebab would not be performed correctly

But for the way his ear tells him to bow

The moon enters the wheel of fate that is the turning wheel of the universe

A face does not see his goodness, even with thousands of eyes. ${ }^{15}$

The song texts in this gathering are some of the few that reference the twelvemaqam system directly, as the songs focus on music and the role of the music in creating a specific experience for those who hear it. The reference to the cupbearer and the ambiguity of meaning in the musical terms maqam and pardeh are all very indicative of this subject matter, yet this is the only gathering where these literary mechanisms appear. Romantic love poetry has better representation in Maraghi's collections, appearing in five different gatherings. Thus, in the thirty-seventh gathering one song sings:

Last night I saw your face in a dream

Seeing the face of the moon is a sign of good luck

Your face, like the sun, is the desire of my heart

This ecstatic heart of mine, oh how sweet, the desire

I see your face everywhere in the mirror of my heart

The mirror of the heart is like the rays of the sun, I do not polish it....

Your eyes are charming, what can I do?

Your hair on your head is starting to seduce, what can I do? 
I was trying not to desire your forearm

Now that it is around my neck, what can I do? ${ }^{16}$

The theme of love in texts recorded from the fifteenth century is at times less romantic and more amusing. A song in the anonymous collection simply states, "When I was young, I had a lot of sex. When I am older, if I have the stamina, I will do it twice as much." ${ }^{17}$ This kind of focus on amusement, fun, and enjoyment apart from dynastic concerns forms the basic premise of several gatherings recorded by Maraghi. His thirty-third gathering is designated for singing anything as long as the song is in a language other than classical Persian. The fortieth gathering is dedicated to nothing but riddles, and the thirty-fourth gathering is an argument between humanity and wine. Here one section of the song presents arguments against the use of wine by a human voice, while in another section the wine replies to speak of its virtues:

He says, "Oh wine! Who are you? Speak!"

The person of religious law has decreed:

Your taste is bitter, your sweetness is sour

You make emptiness and your actions are impious

You deserve the house of the owl, may you be tormented!

[Wine says,] It is permissible to pray with me

My prohibition does not come in the hadith and it does not come in the Qur' an

The Sufi, the person who is inwardly upright; the pious person and the ascetic all

drink me

I do not bring corruption to anyone's door

I solve problems on points of investigation

I make meanings clear in the mind, like the sun. ${ }^{18}$

For all of the various songs that take a somber tone or reflect seriously on the problems of humanity, many of the songs Maraghi records have some amount of levity and wit. Beyond this, several types of songs reflect on aspects of nature, some of which have parallels with writings about the twelve-maqam system. For instance, Maraghi records gatherings dedicated to celebrating different seasons of the year, planets in the sky, and even different times of day, all features of nature tied to the structure of the twelve-maqam system. These topics have a characteristic place in song of the period even as these they contribute to the diversity of interests explored in musical performance.

While the shah stands as the most consistent theme in the songs recorded by Maraghi, the various topics addressed in the songs he recorded are quite diverse. Even the symbolism of the shah has diverse applications. Though always powerful, the shah has paradoxical connotations: he is good, he is bad; he is godlike, he is human; he must be born and he must die; the shah owes much to Islam, and Islam also contains the essence of the shah in its history. Alternatively, the shah could be absent from consideration, as songs and gatherings focused on other topics and 
observations within the human experience. The high degree of abstraction and anonymity found in songs that use the theme of the shah extends to the diversity of topics in Maraghi's collections overall. The beloved is not named in love poetry, and no specific musician is named even when the song is specifically calling upon a musician to play. The audience does not know who is arguing with the wine, and any singer could serve as the voice complaining of getting old.

\section{SINGING FOR THE SAFAVIDS}

While there are significant differences between Safavid songs and the texts of previous collections, there are also some points of commonality. Romantic love and mystical themes are shared between the Safavid and Timurid collections. Amir Khan recorded the following love song in his collection:

The cypresses dance and the roses sway;

Without the starling's song, they bear no delight.

To be with the sweet-lipped and rose-statured lover;

Without a kiss and embrace, it bears no delight

The garden, the rose, and the wine all please, but alas

Without conversation with my love, they bear no delight. ${ }^{19}$

Despite the Safavids' fervent Shi ism, multiple songs reference Sufistic types of mysticism, including sama ${ }^{e}$ and symbolic references to wine:

The mufti has fallen drunk on the seminary door again

His cloak has fallen from his waist, his prayer beads from his hand

The mufti drank from the cup

To nurture his reason and intellect

With each goblet he gave a thousand thanks

To the wine and the wine-seller

Our sheikh drinks the ruby wine to the sounds of the drum and the flute

The town magistrate that plays the tanbur with the flute

Asks for training with the plectrum at the time of prayer ${ }^{20}$

The treatment of romantic love and mysticism in Safavid songs mostly follows trends observable from the previous era. Songs about devotion to God and religious figures, however, are markedly different. This one mystical song is the only song that could be construed as referencing worship of God in the collections of Amir Khan and Aqa Momen Mosannef. Beyond this mystical theme, there is one other that references Islamic figures significant to Shi ism. In another song of Mosannef, one line sings, "Abandon the events of Rostam and Afrasiab. The Shahnameh you must read from is Bu Tarab." ${ }^{21}$ Like Maraghi's eleventh gathering, this line presents a negative view of the legends of pre-Islamic rulers, referencing two kingly names that appear in Ferdowsi's Book of Kings. It further encourages the listener to replace the Shahnameh with stories about 'Ali, a foun- 
dational figure in Shi ${ }^{e}$ a Islam referred to here as Bū Tarab. Despite his significance in Shi'ism, this single reference to Ali is less substantial than the praise he received in Maraghi's gatherings dedicated to praising the companions of the Prophet in general.

It is not only Islam that has less representation in Safavid song. Overall, the songs recorded from the Safavid era do not display the diversity and variety of interests of those recorded by Maraghi. This variety is largely replaced by a greater focus on adoration for the shah, providing florid descriptions of their power and extensive praise for contemporary Safavid rulers. Songs praise specific Safavid rulers in specific ways, often for specific reasons. Even when anonymous, the shah is still overwhelmingly the subject of praise and admiration.

The treatment of the shah in relation to holidays demonstrates the key difference between representations of the shah in Timurid and Safavid song. While Maraghi recorded one gathering generically praising the shah for the celebration of the springtime new year, the Safavid collections contain three separate songs, praising three separate shahs on the occasion of each ruler's specific celebrations of this holiday. Thus, one song sings of Shah 'Abbas II:

In the time of Shah 'Abbas, the shah who established justice

The cupbearer released the wine of justice to the wind

The musician began to play and the lover appeared

Sing two lines, oh nightingale, move around the box tree oh dancer!

It is the day of the new year and the presence of the shah has ignited the gathering

The cupbearers give wine so that in the year there would be such a day

One year comes as the new year grows, may it be blessed

In the feast of the shah, enjoy the delights,

Say to the shah of justice that this is the holiday of the great shahs. ${ }^{22}$

Another song sings of Sultan Husayn:

It is the day of the new year and the drunken flower is in the open meadow. . . .

May the season of spring be to the satisfaction of the king of faith, Sultan Husayn....

He goes like the sun in Aries, the ray of the universe

The shah of faith is in the garden and again the courtyard of the lawn becomes engulfed in light

May the season of spring be to the satisfaction of the king of faith, Sultan Husayn

In the image of the flower, in the embrace of the lover, and feasting in the corner. ${ }^{23}$

While the shah was an abstraction in Maraghi's songs for similar occasions, here the shah is someone specific and this specificity leads to topical redundancy in Safavid songs. It is not that any shah would be celebrated in song on any given occurrence of the new year; it is rather that each specific Safavid shah was celebrated specifically on the new year that they presided over. The natural renewal of spring was tied not just to the dominion of the shah in general, but to the dominion of the specific Safavid ruler in power. Pondering the problems and challenges 
of the ruler was no longer of interest. Praising the Safavid shah and depicting his grandeur were now a primary function of song. Mosannef also recorded a song where the springtime new year served as a royal function granted to a specific shah. Thus, the third song for the new year is a song for Shah Safi (r. 1629-1642), which sings, "they gave you great kingship and divine favor, thankful that the Creator granted sustenance for your renewal; He granted you the new year, conquer, and triumph; my great shah, my heart, may your power be everlasting; the honor of Shah Safi will be the victory of the world; everything his heart wanted, both stated and secret, will happen." ${ }^{24}$

The specificity of both shah and event is also displayed in songs that commemorate specific accessions and victories of shahs. For instance, one song dedicated to the military victory of Shah 'Abbas II in the city of Qandahar sings: "The shah who seized the ground and sky; from the fortune of youth he seized treasure and dignity; Alexander the First is 'Abbas the Second; his blade in an instant seizes heaven and Earth." ${ }_{25}$ This specific praising of a shah in battle reflects Safavid changing topical priorities. The invocation of a historical ruler such as Alexander the Great comes not as a point of reflection, but rather as a device to further praise a Safavid ruler. The reference to 'Abbas II's involvement in heaven and Earth highlights a key aspect of his unique ruling position as a Safavid dynast, who was portrayed as divinity on Earth.

Despite one song containing a short quip against the Ferdowsi's Book of Kings, Safavid song makes use of kingly imagery from the stories in this text in order to depict their dynastic authority. In another song, the justice of Sultan Husayn is compared to that of Nooshirvan, yet another legendary pre-Islamic ruler. ${ }^{26}$ Iran, the legendary domain of ancient rulers such as Nooshirvan, Jamshid, and Hoshang, also becomes a trope that supports the power of Safavid rulers. It is in Safavid song that Iran emerges as a subject of song, standing as a metaphor for the great kingdom that great rulers conquered and controlled. For example, in a song Mosannef wrote to commemorate a victory of Shah Safi's in Iraq, controlling "the army of Iran" validates Shah Safi as a strong dynast, capable of conquering the world:

Telling of the conquest of Baghdad, the story is heard in Rome and India

The shah who took the army of Iran in the direction of Rome

Among the victories of the shah, Najaf was secured and taken

Every individual ponders his person; oh way of respect, move ahead!

The shah won victory and triumph. When Caesar heard, he quit his command. ${ }^{27}$

In this context, the concept of Iran is invoked to represent a great kingdom that the shah controls, which will allow him to conquer more lands. He does not merely rule a place called Iran: he pulls upon it to pursue his conquest of the world. Iran is the proverbial jewel in the crown of the shah, in this case the crown of Shah Safi. 
Iran is featured more prominently in the few generic songs of praise for the shah, where no specific Safavid ruler is named. Thus one song sings:

In traveling the world, I see the countryside

I see scattered ringlets of perfume

Out of season, the dirt yields the rose and the tulip

In the cold season I see spring

May wine and entertainment be abundant for the shah

The world comes from the Iranian king. ${ }^{28}$

Naming no one in particular, this song nevertheless depicts the glory of the shah while using two recurring symbols of Safavid power: control of Iran and the magnificence of spring. The imagery need not be so specific to reinforce the image of Safavid power in song. Mosannef's song for Shah Solomon (r. 1666-1692) uses a more generalized discourse to depict the ruler's power:

Great shah, the condemned planet is not of your command

May everything that is life in the body be your sacrificial offering

The shah is the dome of the crown, the pivot of the kingdom

May you be one of the legs of the throne of Solomon. ${ }^{29}$

Here, Shah Solomon is elevated far above the lowliness of mere physical existence, while the closest the human listener could be to the shah would be to serve as a mere leg on the great shah's throne. It is this nearly deific depiction of the shah that pervades both songs from the collection of Amir Khan and those from Mosannef. While the imagery and context of the shah's greatness vary from song to song, the specificity of praise and admiration for Safavid rule is explicit and detailed. The Safavids wanted more praise for their position in song, and musicians delivered this praise, often in very specific terms.

\section{MUSIC AND THE CHANGING POLITICS OF EMPIRE}

The similarities and differences in topics of song from the Timurids to the Safavids reflect the similarities and differences in the rule of each dynasty and the specific role of music within their distinct discourses of dynastic power. In the context of a ruler's unique ability to engage in military battles and hold great feasts, music had been an aspect of dynastic power's definition in the Persian-speaking world since before the rise of Islam. With Islam came greater interest and ability to maintain and cultivate knowledge as an aspect of dynastic privilege. Music's status as an aspect of knowledge thus became yet another place where it could serve to define and demonstrate the parameters of dynastic power. In both of these capacities, various rulers since the end of the Caliphate adopted the demonstration of control over musical performance and knowledge as an indication of their authority and sovereignty. Turkic and Mongol rulers specifically followed in this tradition with their patronage of music. But the Safavids took these older dynastic traditions and 
used them somewhat differently, focusing less on the cultivation of musical knowledge, and much more on the extent to which music in practice could directly and explicitly voice Safavid power. Rather than passively contributing to the trappings of dynastic authority, Safavid music voiced Safavid dynastic authority in a very literal way: they named and praised specific Safavid rulers, using imagery that referenced tropes of dynastic authority.

The concept of a praise song for a specific ruler was not a regional invention of the Safavids. Long before Maraghi, Mosannef, or Amir Khan, al-Isfahani wrote his extensive Book of Songs (Kitāb al-aghānī), which included many Arabic song texts, including songs of praise for rulers and aristocrats of the 'Abbasid Caliphate. Much larger than the later Persian collections, the Book of Songs covered a wider variety of topics overall, with praise being one of many different possible subjects of song. In this historic context, Safavid praise songs for specific rulers were not something new, even as the lack of such specific praise songs in recorded Timurid and Jalayarid song texts does not mean they were unknown to them or unwelcome in their presence. Yet the disparities between the importance of kingly, musical praise between the two eras highlight shifting priorities. The broad permanence of the shah in the organization and history of human civilization is an important theme in Maraghi's song collections, even as the rarified culture of the courts where he lived valued ownership over a variety of knowledge. Conversely, Safavid court music had a greater emphasis on the glorification of the Safavids in their recorded songs. Kingly praise was the most important priority for songs recorded by Mosannef and Amir Khan. In comparison with Maraghi's collection, the diversity of topics addressed in the songs they recorded decreased, even as overwhelming praise for the shah increased in both quantity and specificity.

The Safavids had more centralized control of their kingdom than their predecessors, and their unique amount of centralized control clearly extended to their music. Whether supporting it or banning music, multiple Safavid rulers were generally more involved in setting a very specific definition of their dynastic personas, and they managed musical output as part of managing very specific aspects of their dynastic visage. They were interested in controlling some details of how music was practiced, at a level of micromanagement unknown to their predecessors. This micromanagement could come in many forms, either actively making music to directly validate Safavid power, or restricting certain types of music to this same end.

As the smallest, most-centralized gunpowder empire, the Safavids directly enacted their power over their kingdom in uniquely performative ways. The historian Kathryn Babayan refers to this as "The Safavi Theater of Authority." ${ }^{\circ}$ Unlike their dynastic predecessors, the Safavids co-opted various types of spaces and community events to demonstrate their kingly omnipotence in the presence of their subjects. Unlike with previous dynasts, the omnipotence of the Safavids included a kind of ambiguous divinity of the Safavids themselves. In making divine power an 
attribute of dynastic power, Shi ism was a key stage upon which the Safavids could act out their divinity. It provided ritual practices the Safavids could co-opt and enact in community space, putting themselves at the center of religious worship. Yet this was not their only stage. From the art and architecture of their capital city to the entertainment in coffee houses and the music of their courts, the Safavids used multiple musical stages to perform their godlike dynastic authority in view of their subjects. In this context, the Safavids would not have songs with religious themes like those of Maraghi. They had separate, performative ceremonies outside of the court to act out their alignment with religious figures.

Before the rise of the Safavids, the relationship between dynasty and Islam was one of mutual confirmation, with religion and empire validating each other. Maraghi documented a song where imagery of shahdom depicted the divinity of God, and another where kingly attributes of the earliest leaders of the Islamic community embodied their greatness as Islamic leaders. Conversely, the Safavids largely position themselves at the center of religious worship. Their predecessors had the kingly trappings of the ruling dynasty as a matter of course, spread out among various cities where branches of the dynastic framework operated. The Safavids tied power very directly to themselves in their capital, where they could control the projection of their power and the acting out of their narrative of divine rule. The fighting and feasting murals and the music room were part of this theater of visually stunning dynastic greatness worthy of worship, in the midst of musical expression that performed this worship.

These differences between Safavid rule and that of their predecessors impacted the written representation of the twelve-maqam system. Before the Safavids, the twelve-maqam system had been discussed in relation to overall knowledge and the complex contemplation of music had been part of a dynasty's unique power over the accumulation and documentation of knowledge in general. It was enough to extrapolate knowledge about music and any number of subjects, giving more complex explanations to demonstrate even more accumulated knowledge. Songs about the shah could highlight this privileged status, yet the control and production of knowledge were more important than using music to provide direct, verbal validation of dynastic rule. Writings about the twelve-maqam system reflect this priority of musical knowledge through to the sixteenth century.

In taking on a new role in the Safavids' theater of authority, musical knowledge for the sake of musical knowledge was not as important. Music's performative power was more important for the Safavids, even as an endless working out of archaic knowledge lost some of its value to more explicit visual representations of power. Thus, writings on the twelve-maqam system in the Safavid empire favored discourse that focused on more idealized visualization of the twelve-maqam system, concentrating on the pattern and schema as well as its idealized power in the world. Even as Shah 'Abbas I sought to make his capital city imitate the appearance of paradise, so too did the twelve-maqam system get caught up in more idealized 
representations of perfection. The basis of its idealized vision predated the Safavids, but it took on an overwhelming dominance in the Safavid domain.

Though the Safavid Dynasty administered their dynastic realm differently than their predecessors, they were still rulers of a dynastic realm, as their songs repeatedly acknowledge. Singing of Iran related directly to aligning Safavid rulers with a history of dynastic legends in the region, even as songs commemorating military victories asserted the Safavids' right to rule far and wide. They were not trying exclusively to rule a place called Iran. Like other empires, the Safavids sought to conquer as much territory as possible. Claiming first and foremost to have conquered the mythological kingdom of ancient kings called Iran bolstered the discourse of their right as dynasts to control any and all lands. Thus, the Safavid capital in Isfahan earned the title "half the world" (nesf-i jahān), and the Safavids pursued the possibility of ruling and subjugating lands over as much of the Asian continent as possible.

The Safavids had to keep pushing out from the lands they could control at any given moment, as Ottoman and Mughal leaders sought their own expansion of power alongside local leaders seeking to assert their own dynastic status. The Russian Empire's expansion into Ottoman and Safavid lands represented one element that contributed to the Safavid's downfall. The Afghan invasion represented yet another direct challenge to the Safavid's right to rule that they ultimately could not withstand.

In the end, the Safavids failed to maintain any significant growth of their kingdom. Despite songs praising specific Safavid victories and the subsequent conquering of new territory, the Safavids did not hold on to much territory they conquered from their imperial neighbors. The extreme centralization of their realm did relate to their inability to expand their domain and protect it from being overtaken. It was simply not possible for a dynast to administer, protect, and expand the realm without some of the more diffuse aspects of empire, especially more diffuse military support.

As more aspects of empire came to be run directly from Safavid palaces in the wake of difficult economic conditions, the Safavids set themselves on a course that contributed to their downfall..$^{31}$ The unique aspects of Safavid rule that contributed to a more direct deployment of music to serve Safavid interests also left the last Safavid rulers too weak to maintain their kingdom against foreign invasion. The Afghan invasion in 1722 ended Safavid rule in a very dramatic fashion, but not before Safavid decisions concerning the administration of their kingdom had left them susceptible to such an invasion.

The particular way Safavid rule ended resulted in a period of subsequent political chaos unique in the history of court patronage surrounding the twelve-maqam system. As a result, it began to lose standing as the focal point of music's conception. The twelve-maqam system had thrived in the midst of relatively consistent dynastic governance, but having a significant portion of its domain lacking stable 
patronage over decades had a significant impact on its relevance in the world. The twelve-maqam system in the eighteenth century was defined by how regularly it appeared alongside other ideas about music's structure. Sometimes it stood as a rhetorical device to legitimate a second music system; other times it stood as a coequal, alternative method of discussing a second music system. Dynastic politics was a key cultural factor that determined many of the possibilities for music's structure and practice, and thus the power of the twelve-maqam system weakened as dynastic institutions weakened. This allowed for other concepts of musical structure to usurp the twelve-maqam system's presence and power, a reality that created a whole new landscape for music in the nineteenth-century court of the Qajar Dynasty. 